\title{
KOMIKS AUTOBIOGRAFICZNY W KONTEKŚCIE DYDAKTYKI WIEDZY O KRAJU NA PRZYKLADZIE KOMIKSU MARZI
}

SŁowA KLUCZOWE: język polski jako obcy, wiedza o kraju, najnowsza historia Polski, glottodydaktyka, komiks autobiograficzny, Marzi

\section{Wstęp}

Jedną z możliwości kształcenia sprawności i przekazywania odpowiednich treści kulturowo-językowych jest korzystanie $z$ autobiograficznych komiksów ${ }^{1}$. Niniejsza publikacja przedstawia sposób przekazania uczniom języka polskiego jako obcego niezbędnych informacji o Polsce, które mogą być pomocne w zrozumieniu pojęć kulturowych i udoskonaliłyby ponadto sprawności czytania, mówienia, pisania i rozumienia ze słuchu w języku polskim. Na przykładzie wybranych paneli z komiksu Marzi pragnę przedstawić możliwości, które mogą wspierać zajęcia z języka polskiego dla zaawansowanych, wykorzystując do tego fragmenty komiksu odnoszącego się do najnowszej historii Polski.

${ }^{1}$ Do dziś nie ma powszechnie obowiązującej definicji pojęcia komiks. Wskazywane są odnośnie tego dwie przyczyny. Po pierwsze, do niedawna nie postrzegano komiksów jako niezależne medium. Oprócz tego, wartościowanie komiksów odbywało się z określonego punktu widzenia, tzn. z punktu widzenia literatury. Po drugie, po długiej fazie stagnacji (do lat 90-tych) komiks zaczął się intensywnie rozwijać, co doprowadziło do poszerzania się ogólnie pojętych ram komiksu i łamania własnych konwencji zarówno twórczych, jak i przekazowych. Dlatego wychodzi on poza dotychczasowe granice medialne i próbuje swoich sił na nowych płaszczyznach gatunkowych. Ponadto, definicje z nim związane są stworzone z perspektywy pewnej dyscypliny naukowej. W definicjach komiksu często ani nie uwzględnia się aspektu kulturowej zależności medium, ani aktywnego działania odbiorcy. Każda definicja jest więc tymczasowa. Dlatego najodpowiedniejsze są te z nich, które traktują komiks możliwie szeroko, na podstawie najniższego wspólnego mianownika. Takie definicje stworzyli m.in. W. Eisner i S. McCloud. Eisner nazwał komiks ,sztuką sekwencyjną” [zob. Eisner, 2008]. Według McCloud, komiks to obrazowe lub inne znaki, układane jako przestrzenne sekwencje, które przekazuja informacje i/lub wywołują estetyczny efekt u odbiorcy [zob. McCloud, 1994]. Według mnie, komiks jest niezależnym medium, które może korzystać z abstrakcyjnych znaków oraz mniej lub bardziej realistycznych ikon (rysunków), ażeby za pomocą technik narracyjnych obowiązujących w danej kulturze stworzyć nowy środek przekazu. Komiksy działają dwukanałowo poprzez kombinację środków literackich i percepcję wizualną. Decydującą cechą jest fakt, że odbiorca musi nieustannie interpretować wypowiedź komiksu i weryfikować swoją interpretację w trakcie percepcji kolejnych paneli. Musi aktywnie uczestniczyć w krystalizowaniu fabuły i przekazu danego komiksu, analizując nie tylko współgrę pomiędzy tekstem a rysunkiem, lecz również pomiędzy pojedynczymi panelami i tym, co nie jest jednoznacznie wskazane, ale oznaczone poprzez tzw. gutter. 
W przedłożonym materiale można wyodrębnić trzy części. Pierwsza dotyczy grupy docelowej. Druga przedstawia serię komiksów Marzi, które wymieniam w związku z analizą wybranych elementów oraz ich autorów. W ostatniej części publikacji proponuje metody stosowania komiksu Marzi na zajęciach z języka polskiego jako obcego dla zaawansowanych, przede wszystkim dla niemieckojęzycznych interesentów (ale nie tylko).

\section{Opis grupy docelowej}

Język polski należy do zachodniosłowiańskich języków wąsko rozpowszechnionych w niemieckojęzycznej kulturze nauczania języków obcych. Sytuacja ta wiąże się przede wszystkim z dotychczasowym rozwojem kulturowo-społecznym krajów zachodnich, których obywatele preferowali naukę języków obcych zapowiadających w kontaktach ekonomicznych odpowiednie długoterminowe korzyści. Ze względu na to, że Polska długo nie należała do czołówki gospodarczej, z której można byłoby otrzymywać zamierzone profity gospodarcze, język polski zaczął nabierać na wartości dopiero na początku lat 90-tych. Zainteresowanie językiem polskim w niemieckojęzycznym obszarze zaczęło się od tego umownego momentu zmieniać, ale nadal znajduje się w stanie rozwoju².

Także inne kręgi społeczne w Niemczech szukające nowych wyzwań zawodowych decydują się $\mathrm{w}$ większości na doskonalenie obcojęzyczne w dominujących językach zachodniej Europy. Dlatego szkoły językowe w Niemczech preferują przede wszystkim naukę takich języków jak angielskiego, francuskiego lub hiszpańskiego. Jedną z bardzo nielicznych możliwości uczenia się polskiego oferują instytuty polonistyczne na uniwersytetach, lecz poziom kursów rzadko przekracza $\mathrm{C} 1$. Z tego względu seminaria o języku, o literaturze lub o kulturze polskiej często prowadzi się po niemiecku, a studentów zachęca się do wyjazdu do Polski, ażeby tam zdobyli niezbędne kwalifikacje językowe. $Z$ tych powodów do grupy docelowej należą moim zdaniem prawie wyłącznie studenci polonistyki, zarówno ci z rodzin niemieckich, jak i ci z rodzin polonijnych. Jest to związane ze wspomnianym już problemem nauki języka polskiego poza granicami kraju. Poloniści i studenci z rodzin polonijnych posiadają odpowiednio rozwiniętą znajomość języka polskiego (w przeciwieństwie do innych grup społecznych), które umożliwiają im prawidłowy dostęp do wspomnianej wyżej dydaktyki językowej. Dla innych grup społecznych nakład pracy w naukę języka na podstawie komiksów jest nieporównywalnie wyższy do szybkich korzyści, jakich by oni oczekiwali z powyższej metody nauczania.

${ }^{2}$ Braku motywacji i możliwości uczenia się języka polskiego w Niemczech nie można porównać niestety z brakiem zainteresowania kulturą polską, co mogłoby być przedmiotem interesującego i obszernego dyskursu. Ponadto trzeba zaznaczyć, że szkoły językowe w Niemczech nie posiadają — według moich doświadczeń zawodowych — tak wysokiego znaczenia społecznego w kształtowaniu wizerunku zawodowego pośród młodego pokolenia, jak w Polsce, gdzie intensywnie inwestuje się w rozwój indywidualnych zdolności językowych. 


\section{Marzi}

\subsection{O zespole autorów i o serii komiksów Marzi}

Marzi to nie tylko tytuł serii komiksów o wspomnieniach dorosłej kobiety z punktu widzenia małoletniej dziewczynki. Marzi to też pseudonim z dzieciństwa autorki, Marzeny Sowy, która opowiadała swojemu partnerowi, grafikowi Sylvain Savoia, o życiu w PRL i Polsce. Zainspirowany jej opowiadaniami, zaczął ilustrować teksty z małą Marzi w roli głównej.

Postać, która została stworzona głównie dla Francuzów i starszych dzieci Polonii francuskiej, odniosła ogromny sukces nie tylko we Francji, lecz także w Polsce. Opowiadania o przeżyciach małej rudowłosej dziewczynki z historią PRL i kulturą polską w tle zawierają dużo wzmianek o polskiej polityce oraz historii najnowszej, co zaciekawiło sporą grupę w innych krajach — i nie tylko Polonię. Pierwotnie komiksy ukazały się we francuskiej wersji językowej w sześciu tomach. Marzi została przetłumaczona przez samą Marzenę Sowę na język polski (w trzech tomach). Inne tłumaczenia ukazały się w języku chińskim, koreańskim, włoskim, niemieckim, hiszpańskim lub angielskim. Zaplanowany jest ciąg dalszy jej historii oraz film.

\subsection{O strukturze Marzi}

Podczas analizy komiksu najważniejszymi aspektami są obraz oraz tekst. Te dwa elementy, współpracując ze sobą tworzą spójne przesłanie tego, co autor i rysownik chcieli przekazać czytelnikowi.

Struktura pojedynczych opowiadań w Marzi nie jest skomplikowana i prawie zawsze identyczna: Na jednej stronie widać sześć paneli, które należy czytać od lewej do prawej oraz z góry na dół, co odpowiada naszemu, europejskiemu sposobowi percepcji. W panelach mogą wystąpić dwa rodzaje tekstów oraz dwa rodzaje rysunków. Pierwszy rodzaj tekstu to teksty nad albo pod rysunkiem, który jeszcze znajduje się $\mathrm{w}$ ramce panelu. Jest to tekst wypowiedziany przez narratora ${ }^{3}$, tzn. przez dorosłą Marzi, „wspominającą” opowiadaną historię. Drugi rodzaj tekstu to tekst w dymkach, to znaczy, dialog bohaterów rysunku. Relacja między rodzajami tekstów odzwierciedla się też na osi czasu: narrator znajduje się w teraźniejszości, natomiast opowiadany tekst sytuuje wspomnienia w postaci rysunków oraz dialogów w przeszłości. $\mathrm{Na}$ tę relację same panele nie wskazują, wręcz przeciwnie. Są utrzymane w bardzo konwencjonalnym stylu, który sugeruje niezależność od czasu. To znaczy, że rysunki i tekst są sprzeczne z logiką czasową, ponieważ rysunki wydają się bardziej aktualne i bardziej prawdziwe od tekstu narratora. Efektem tego sposobu narracji jest częste przenoszenie punktu ciężkości z tekstu narratora na rysunki i dialogi bohaterów.

Relacja tekst - rysunek ma prostą strukturę z silnym przesunięciem punktu ciężkości na rzecz tekstu narratora. Prawie zawsze rysunki przekazują i utwierdzają tyl-

${ }^{3}$ Obecność narratora, który wtrąca się spoza rysunku tworzy ramę dla rozwoju akcji oraz dla dynamiki dialogów. 
ko to, co zostało wcześniej opisane w tekście narratora. Dlatego właśnie on jest obciążony przesłaniem komiksu. Fakt ten ma konsekwencje w odbiorze estetycznym: niektóre opowiadania w Marzi zdają się być raczej ilustrowanym tekstem, aniżeli komiksem (w którym tekst i rysunek współpracują w imię zamierzonego przekazania przesłania, czy też konkluzji potencjalnemu odbiorcy). Zwłaszcza tom Nie ma wolności bez solidarności wymaga od odbiorcy raczej percepcji tekstu, co się oczywiście może „odbijać” na interpretacji rysunków. Dość często ominięto przez to w wymienionym tomie współdziałanie tekstu, rysunku i paneli. Marzi zawiera bardzo mało dialogów w porównaniu do narracyjnego tekstu. Jeżeli są, to mają odpowiednie funkcje: albo współgrają z tekstem narratora i udają wspomniany dialog między prawdziwymi postaciami (efekt uautentycznienia) ${ }^{4}$, albo sprowadzają bohatera ze świata wyobrażonego do (opowiadanej) „rzeczywistości”. Mogą też służyć podkreśleniu stanu emocjonalnego bohaterów, to znaczy, mają efekt dramatyzacji i umacniają dynamikę 6 . Dwom rodzajom tekstów odpowiadają dwa rodzaje rysunków. Pierwszy typ to ilustracja wspomnień kobiecego narratora, rysunki są typowo komiksowe, to znaczy, zredukowane do niezbędnej informacji, żeby czytelnik mógł zidentyfikować przedstawiony świat i utożsamić się z nim. Drugi rodzaj rysunków symbolizuje wtrącanie fragmentów z rzeczywistości w fikcję: jeżeli w narracji pojawiają się elementy autentyczne lub historyczne postaci, wtedy używany jest inny sposób ilustracji, bardziej realistyczny i mniej abstrakcyjny, często też z inną kolorystyką̧ ${ }^{7}$ Te różnice wydają mi się dosyć ważne w dydaktycznej pracy z komiksem Marzi na zajęciach.

\subsection{Analiza wybranych elementów}

W Marzi poświęcono polityce dużo miejsca, zwłaszcza w tomie Nie ma wolności bez solidarności. Głównym tematem komiksu są strajki huty w Stalowej Woli oraz reakcje ze strony społeczeństwa i polityków PRL. Przedstawione są też obyczaje polskie, tęsknota za produktami z zachodu, trudności życia codziennego, od braku towarów i długich kolejek począwszy, po katolicyzm i wzajemne wspieranie się ludzi.

Materiał jest obfity, dlatego nie łatwo się zdecydować na pojedyncze epizody. Wybrałam kilka paneli, które wydają mi się odpowiednie z punktu widzenia niemieckiego zainteresowanego. Pierwszy przykład to panel z epizodu „Żegnaj, laleczko", w którym Marzi wraz ze swoimi rodzicami odwiedza rodzinę ze strony matki na wsi. Ani Marzi, ani jej ociec nie spotkali tej części rodziny wcześniej. Już po paru godzinach, kiedy Marzi i jej kuzynka leżą w łóżku, dziewczynka jest

${ }^{4}$ Odwołania do paneli podane są w następujący sposób: tom komiksu, tytuł epizodu, strona w tomie, numer panelu na danej stronie. Tu: Marzi 1: Dzieci i ryby głosu nie maja, ,Reality TV”, 55, 1.

5 Tamże.

6 Tamże, „Oddychanie może być bardzo szkodliwe dla zdrowia”, 91, 4.

7 Marzi 3: Nie ma wolności bez solidarności, „Rycerze Okrągłego Stołu i dwa kajaki”, 19, 3-6. Por. też Tabl. 3. 
świadkiem zaciętej dyskusji pomiędzy jej ojcem i jego szwagrem. Kłócą się o przyczyny wprowadzenia stanu wojennego:

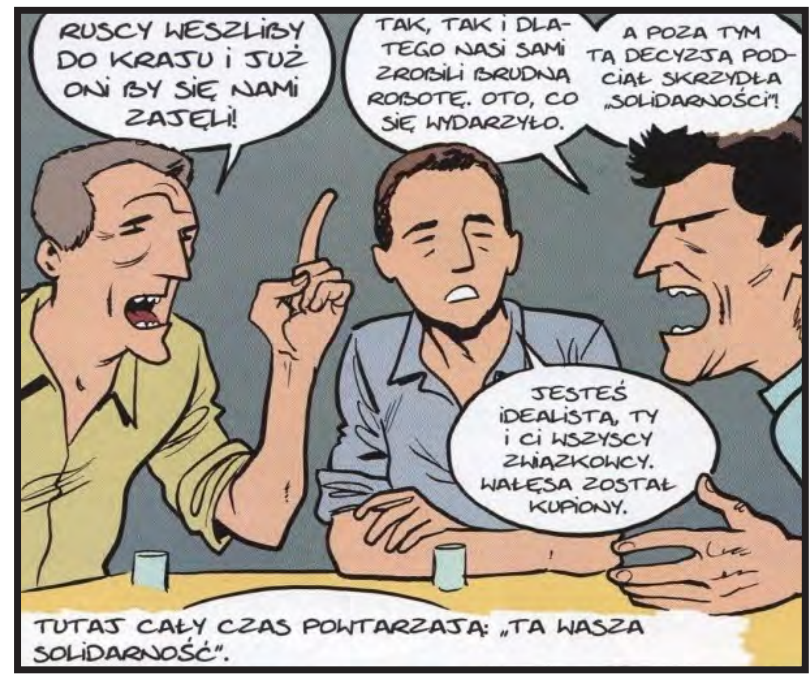

Tabl. 1. Marzi 3: „Żegnaj, laleczko”, 39, 6

$\mathrm{Na} \mathrm{każdym} \mathrm{obcokrajowcu}$ uczącym się języka polskiego musi to robić dziwne wrażenie: członkowie rodziny znający się dopiero od kilku godzin, żyjący w państwie, które jeszcze jest lub do niedawna było państwem silnie autorytarnym ${ }^{8}$, gdzie każdy może okazać się szpiclem lub tzw. TW czy ubekiem, a przy stole dwaj dorośli mężczyźni tak zaciekle dyskutują o polityce, że o mały włos nie dochodzi do rękoczynów. Można by wnioskować, że Polacy uwielbiają dyskutować o polityce i robią to z werwą. Wszystko im jedno, do czego to doprowadzi, nie liczą się z konsekwencjami.

Jednak ani z rysunków, ani z tekstu czytelnik się nie dowie, że zarówno ojciec jak i jego szwagier reprezentują tu typowe wówczas stanowiska w debacie wokół wprowadzenia stanu wojennego. Opisane są tu dwa główne nurty, które w Polsce są szeroko dyskutowane i wywołują publiczne emocje:

1. Przez wprowadzenie stanu wojennego Jaruzelski zapobiegł wkroczeniu sowieckich wojsk do Polski (na rysunku nazwanych: „Ruscy”, co dodatkowo określa stosunek szwagra do Rosjan), żeby nie dopuścić do powtórzenia sytuacji z Pragi. Takie stanowisko reprezentuje wujek Marzi.

2. Inny punkt widzenia reprezentowany jest przez ojca Marzi, według którego Jaruzelski nie tylko zbyt pochopnie zrobił to, czego Kreml od niego oczekiwał, lecz także podjął walkę przeciw własnemu narodowi oraz ograniczał demokratyczny rozwój ruchu solidarnościowego.

W panelu widać też syna szwagra, podchodzącego raczej pragmatycznie do sprawy. On nazywa ojca Marzi idealistą ze związku zawodowego, który nie uświadomił sobie jeszcze, że jego starania są daremne, bo sam przywódca związku, Lech Wałęsa, zostat kupiony.

${ }^{8}$ W komiksach nie ma wzmianek o czasie, w którym toczy się akcja. Trzeba wyjść z założenia, że w Marzi obowiązuje chronologia na osi czasu, w takim razie akcja $\mathrm{z}$ tego epizodu miałaby miejsce po upadku muru berlińskiego (tamże, „Rycerze Okrągłego Stołu i dwa kajaki”, 23, 2), ale przed drugą turą wyborów prezydenckich 1990 r. (tamże, „Ciężar wolności”, s. 51, 3-4), a więc po 9.11.1989 r., ale przed 9.12.1990 $\mathrm{r}$. 
Na zajęciach można nie tylko pracować nad stanowiskami w sprawie wprowadzenia stanu wojennego, lecz można też porównać znaczenie związków zawodowych w Niemczech i w Polsce, ponieważ w każdym z tych krajów jest inne postrzeganie spraw związkowych przez społeczeństwo, zwłaszcza, jeżeli chodzi o lata 80-te. W Niemczech związki zawodowe walczą bardzo umiarkowanie o wyższe zarobki swoich członków i także w umiarkowany sposób reprezentują ich interesy w pracy. W Polsce natomiast związki zawodowe przyczyniły się także do zmiany systemu politycznego w bloku wschodnim. Ich funkcja ma do dziś charakter polityczny, są poniekąd nieodłącznym elementem tzw. polityki niezależnej (dla przypomnienia można wymienić strajk pielęgniarek i namiotowe miasteczko przed Sejmem), chociaż tracą po części w tym sektorze na znaczeniu. W Niemczech związki zawodowe też mają wpływ polityczny, jednak ich znaczenie ważnego gracza współbudującego i zmieniającego społeczeństwo jest mocno ograniczone. Swoje najlepsze lata pod tym względem miały na początku XX wieku oraz w latach 60-tych, o czym niestety nie tylko młodzi studenci często nie wiedzą (to tylko na marginesie).

Drugi przykład to fragment ilustrujący tekst narratora. Panel pochodzi z tomu Nie ma wolności bez solidarności (s. 2). W epizodzie narrator opowiada o tym, że społeczeństwo w Polsce pomimo brutalnych represji ze strony reżimu coraz głośniej i odważnej mówi „Nie!”:

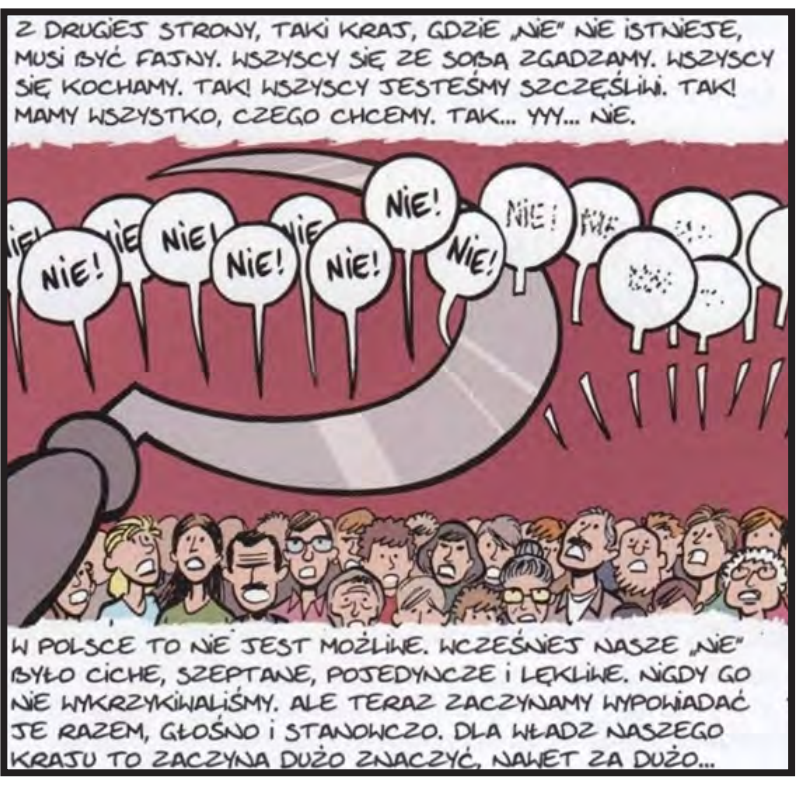

Tabl. 2. Marzi 3: „Jedenaście dni, jedenaście nocy”, 4, 1

Panel przedstawia sierp, który przecina dymki $\mathrm{z}$ tekstem „Nie!”. Interesujące jest to, że w panelu zmienia się kierunek odczytywania rysunku. W każdym innym panelu pokrywa się on z kierunkiem czytania tekstu pisanego, a więc od lewej do prawej. Tu jednak trzeba czytać od prawej do lewej (biorąc pod uwagę kierunki geograficzne: od wschodu do zachodu). Na pierwszy rzut oka jest to zastanawiająca sprzeczność przyjętej konwencji percepcji, która zmusza czytelnika do refleksji nad znaczeniem obrazu. Dopiero po kilkakrotnym przeczytaniu uświadamia on sobie, że transparentny zapis słowa „Nie!” nie oznacza, że słowo to (a z nim ludzie) umiera, lecz to, że jest ono przemocą oderwane od sprzeciwiającego się społeczeństwa - trzeba zauważyć przy interpretacji tego panelu, że słowo „Nie!” w odciętych dymkach jakby traciło na sile przebicia, co jest zaznaczone trans- 
parentną czcionką, w przeciwieństwie do nieodciętych sierpem dymków, gdzie słowo „Nie!” posiada „silną”, wyrazistą, thustą czcionkę. Trzeba dodać, że i przed, i po tym panelu, nie było żadnej wzmianki o ZSRR. Wniosek jest jednak jednoznaczny. Sierp jest jednym z dwóch elementów flagi ZSRR i często służy do identyfikacji Kraju Rad (rzadko kiedy krytycy Związku Sowieckiego posługą się symbolem młota), a w tym panelu sierp jest właśnie tak przedstawiony, jak w symbolice ZSRR (stąd też prawdopodobnie zamierzona sprzeczność kierunku odczytu). Natomiast godłem państwowym PRL był biały orzeł bez korony na czerwonym tle. A zatem: za władzami PRL stoi Kreml, który dyktuje politykę w Polsce.

Trzeci i ostatni przykład pokazuje powiązanie rzeczywistości z fikcją poprzez sposób rysowania:

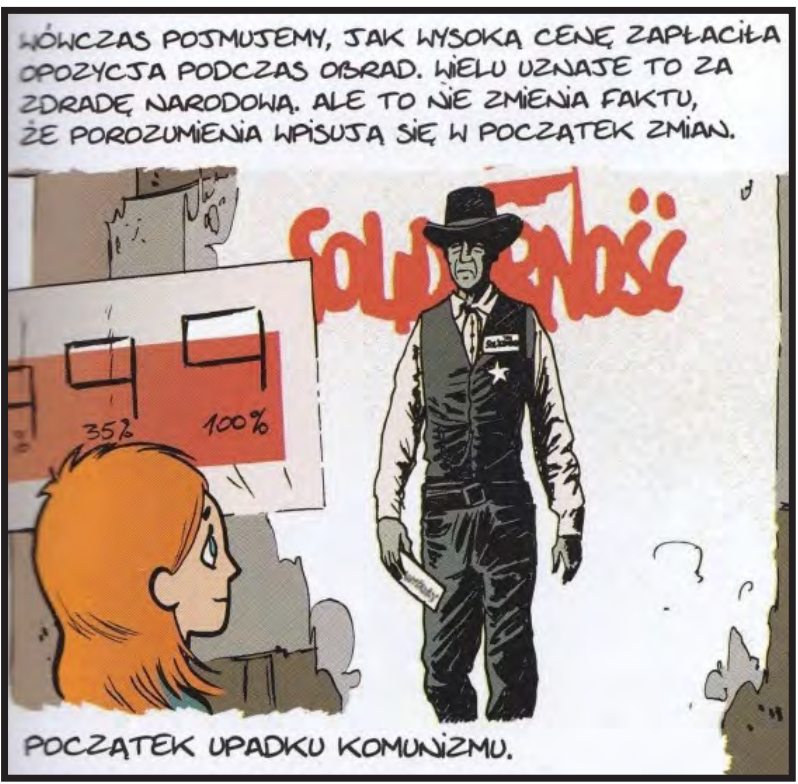

Tabl. 3. Marzi 3: „Rycerze Okrągłego Stołu i dwa kajaki”, 21, 5

$\mathrm{Na}$ wybranym panelu widać postać szeryfa z logo Solidarności w tle. To cytat z plakatu z kampanii wyborczej autorstwa Tomasza Sarneckiego. Oryginał zawiera tekst $W$ samo poludnie 4 czerwca 1989 i zachęca obywateli do głosowania na Solidarność w pierwszych tak zwanych wolnych wyborach (lub też wyborach kontraktowych) w dn. 4 czerwca 1989 r. Przedstawiony szeryf trzyma $\mathrm{w}$ ręku arkusz z napisem $W y$ bory, na piersi, nad gwiazdą szeryfa, ma naszywkę Solidarności. Postać szeryfa nie jest przypadkowa, to Gary Cooper z W samo potudnie, który w filmie odgrywa rolę samotnego bohatera walczącego o dobro i sprawiedliwość. Plakat ten zrobił także na mnie duże wrażenie, kiedy, studiując w Warszawie, po raz pierwszy go zobaczyłam. Zrozumiałam wtedy, jak ogromne znaczenie ma dla Polaków wywalczona wolność, czego wcześniej nigdy sobie nie uświadamiałam. Wiedza o tym, że wolność może być zagrożona, jest dla wielu młodych ludzi wiedzą zdobytą w szkole oraz poprzez dyskusje w rodzinie. Im większy odstęp między walką o wolność a teraźniejszością, tym trudniej o intertekstualne postrzeganie aluzji i stosowną interpretację przedstawionego na rysunku symbolu. Dlatego myślę, że niemieckojęzyczny uczący się (ale nie tylko) zidentyfikowałby może Garry'ego Coopera i pomyślałby, że rozchodzi się tu o samą walkę, o tło dzikiego zachodu lub o bohatera, który stawia czoło jakiemuś złu, jednak bez zrozumienia roli Solidarności w Polsce nie jest w stanie połączyć interpretacji postaci szeryfa z pierwszymi wolnymi wyborami w Polsce. Bez wytłumaczenia o tym 
fakcie i posiadania odpowiedniej wiedzy o historii Polski nie zrozumiałby, dlaczego Polacy tak wysoko cenią sobie wolność i mógłby pomyśleć, że lubią dramatyzować politykę. ${ }^{9}$

\section{Wnioski dla wykorzystania komiksu w dydaktyce języka polskiego jako obcego na poziomie zaawansowanym}

Nauczyciel, który chce uświadomić swoim uczniom specyfikę życia w PRL oraz polskiej kultury, może na zajęciach z języka polskiego jako obcego na poziomie zaawansowanym w różny sposób korzystać z Marzi i zachęcić lub przygotować uczniów do wypowiedzi ustnej ${ }^{10}$. Ażeby skonkretyzować propozycje dydaktyczne, chciałabym przedstawić przykładowy scenariusz lekcji opartej o panel z plakatem wyborczym Solidarności (Tabl. 3).

\section{Scenariusz zajęć}

\begin{tabular}{|c|c|}
\hline Temat sekwencji & Pierwsze wolne wybory i upadek komunizmu \\
\hline Temat lekcji & Symbole pierwszych wolnych wyborów w Polsce \\
\hline Adresaci & Obcokrajowcy, studenci polonistyki (od ok. 20 lat, poziom C1); 9 osób \\
\hline $\begin{array}{l}\text { Miejsce realizacji } \\
\text { zajęć }\end{array}$ & Sala komputerowa \\
\hline Czas realizacji zajęć & 90 minut \\
\hline Cele zajęć & $\begin{array}{l}\text { Zapoznanie się z okresem przedwyborczym w trakcie przemian po- } \\
\text { litycznych. Wnioski kulturoznawcze na podstawie epizodu Marzi 3: } \\
\text { „Rycerze Okrągłego Stołu i dwa kajaki”, s. 17-23. Przy szczególnym } \\
\text { uwzględnieniu plakatu wyborczego Solidarności z } 1989 \text { r. tak, aby po } \\
\text { zajęciach studentki i studenci potrafili: } \\
\text { - szczegółowo opisać plakat wyborczy Solidarności z } 1989 \text { r., } \\
\text { - zinterpretować i wytłumaczyć jego symbolikę, } \\
\text { - wypowiedzieć się, dlaczego powstał, jakie ma przesłanie, jakie ma } \\
\text { znacznie dla odbiorców, } \\
\text { - ustosunkować się do plakatu wyborczego. }\end{array}$ \\
\hline Metody pracy & $\begin{array}{l}\text { - } \text { praca z komputerem } \\
\text { - zbieranie i przetwarzanie informacji } \\
\text { - relacjonowanie wyników pracy (z wyznaczeniem otwartych pytań) } \\
\text { - rozmowa/dyskusja na dany temat }\end{array}$ \\
\hline
\end{tabular}

${ }^{9}$ Nie zrozumiałby również, dlaczego obraz szeryfa z amerykańskiego westernu jest w takim stopniu przekonujący dla Polaków, że nie kwestionują używania symbolu pochodzącego z innej kultury, wręcz przeciwnie, łatwo zaadaptowali go do swojej.

${ }^{10}$ Podstawą jest, oczywiście, znajomość potrzebnego słownictwa przez uczniów. 


\begin{tabular}{ll}
\hline Formy pracy & praca z kursem w fazie wstępnej oraz w fazie podsumowującej \\
& praca grupowa w fazie realizacyjnej (3 grupy, studenci sami mogą \\
& tworzyć zespoły) \\
\hline Środki dydaktyczne & rzutnik multimedialny, laptop i slajd plakatu wyborczego \\
& komputery z dostępem do Internetu \\
& zeszyty i długopisy do sporządzenia notatek \\
& arkusze formatu A3 i pisaki do prezentowania wyników pracy \\
& epizod z komiksu Marzi 3: „Rycerze Okrągłego Stołu i dwa kajaki”, \\
& s. 17-23 oraz zbiór ćwiczeń do niego (praca domowa) \\
\hline
\end{tabular}

Przebieg zajęć

Faza wstępna.

Wprowadzenie do tematu

Studentom przedstawiony zostaje w/w epizod z komiksu Marzi. Podczas przedstawienia epizodu szczególny nacisk zostaje położony na symboliczny element epizodu. W tym przypadku jest to plakat wyborczy Solidarności (Tabl. 3), który będzie wyświetlony za pomocą projektora na ekranie (ścianie). Pojedyncze osoby proszone są o możliwie szczegółowy opis panelu z tym plakatem. Następuje interpretacja, do której, jeżeli nikt się nie zgłosi, zachęceni są najlepsi uczestnicy. Nauczyciel może pomóc pierwszymi pytaniami: Dlaczego pokazany jest szeryf? Kogo przypomina ta postać? Dlaczego widać logo Solidarności?

Czas: $15 \mathrm{~min}$

Faza wstępna.

Przygotowanie fazy realizacyjnej / organizacja

Faza realizacyjna. Pozyskiwanie danych

Powtórne przedstawienie tematu lekcji, podział kursu na grupy, rozdanie materiałów (arkusze, pisaki), wyjaśnienia zadania i przedstawienie przebiegu lekcji oraz pracy domowej.

Czas: $2 \mathrm{~min}$

W grupach studenci zbierają informacje odnośnie plakatu (grupa 1), Solidarności (grupa 2) i odnośnie pierwszych wolnych wyborów (grupa 3) w Internecie. Kursanci wiedzą, że ich zadanie polega na przedstawieniu rezultatów w sposób spójny z innymi studentami z grupy. W swojej relacji mają uwzględnić nowe słownictwo. Nauczyciel przypomina, że ważne jest źródło informacji i zachęca do trzymania wobec niego dystansu. Pomaga studentom ze słownictwem i z orientacją na stronach internetowych. Jeżeli jest taka potrzeba, wskazuje na ważne informacje.

Czas: $20 \mathrm{~min}$

Faza realizacyjna.

Przetwarzanie i analiza danych
Studenci analizują zebrane informacje i podporządkowują je pod względem zadania. Przedstawiają krótko plakat, Związek Zawodowy Solidarność oraz wolne wybory. Tworzą mały słowniczek tematyczny z nowymi słowami i zwrotami. Zbierają na arkuszach najważniejsze informacje odnośnie swojego tematu.

Czas: $15 \mathrm{~min}$ 


\section{Faza realizacyjna.}

Prezentacja danych
Wszystkie trzy grupy przedstawiają wyniki swoich prac (prezentacja) oraz słowniczek tematyczny swojego tematu oparty na przygotowywanym materiale informacyjnym. Każdy członek zespołu musi przedstawić fragment. Potem inni uczestnicy muszą zadawać pytania, na które grupa ma opowiadać.

Czas: 25 min
Podsumowanie wyników pracy i wnioski z prezentacji wykonane przez nauczyciela — przy szczególnym uwzględnieniu wymienionego epizodu. Czas: 5 min

\section{Czas: $4 \mathrm{~min}$}

Przedstawienie pracy Czas: 4 min
domowej

Czas zapasowy na
sprawy organizacyjne

Praca domowa

Opracowanie zbioru ćwiczeń dydaktycznych (poniżej) do wybranego epizodu w celu przygotowania studentów do następnych lekcji. Praca domowa opiera się na ćwiczeniach z zakresu rozumienia tekstu pisanego (rozumienie globalne, selektywne i szczegółowe). Praca domowa zachęca studentów do wypowiedzi pisemnej oraz do przygotowania wypowiedzi ustnej (opracowanie niezbędnego słownictwa, zachęcanie do refleksji nad zagadnieniami związanymi z tematyką sekwencji, zachęcenie do poszukiwania informacji w celu rozumienia epizodu i sporządzenia notatek).

Ewaluacja

Wspólne omawianie pracy domowej na następnych zajęciach, sprawdzenie wypowiedzi pisemnej, zachęcenie studentów do zadawania pytań odnośnie epizodu w celu wyjaśnienia niejasności oraz poznawania braków wiedzy.

\section{PRZYKŁADOWY ZBIÓR ĆWICZEŃ DO PRACY DOMOWEJ}

\section{Zadania związane z epizodem „Rycerze Okrągłego Stołu i dwa kajaki”}

I. Rozumienie tekstu.

1. Przeczytaj opowiadanie „Rycerze Okrągłego Stołu i dwa kajaki” i odpowiedz na następujące pytania:

a) Jak postać Marzi i jej rodzina doświadczają opisany okres?

b) Jakie postaci i zagadnienia historyczne są wymienione? Czego się o nich dowiedziałeś/ dowiedziałaś?

c) Jak według tekstu przebiegł czas od przygotowania do Okrągłego Stołu do pierwszych wolnych wyborów?

d) Jak reagują ,zwykli” ludzie, według epizodu, na nową sytuację (a) życiową, b) obyczajową i (c) polityczną? Jak narrator ocenia obrady okrągłego stołu i pierwsze wolne wybory? Uzasadnij Twoją interpretację! Co myślisz — dlaczego te postawy się różnią?

2. Jak rozumiesz następujące fragmenty z epizodu? Uzasadnij Twoją interpretację!

a) Pogoda jest niczym lustro dla stanu ducha dorostych. (s. 18)

b) Każą nam nagle wrzucić piąty bieg, którego nasze Maluchy przecież nie mają. (s. 20)

c) Wtedy Polacy odkrywaja to, co zaserwowano im przy Okragtym Stole. (s. 21)

3. Czy tekst zawiera niewyjaśnione dla Ciebie informacje? Jeżeli tak, to jakie? 
II. Słownictwo.

1. Wytłumacz własnymi słowami, co oznaczają następujące słowa i zwroty:

a) obawy okazuja się stuszne

b) jakby wnętrzności zaciskały się w supet

c) niestrudzenie protestować

d) rozejść się po kościach

e) przeszywajace zimne wiatry

f) poczucie marazmu

g) pewien fakt przyćmiewa nasza radość

h) miażḋaca przewaga

2. Wybierz 5 nieznanych Ci słów lub zwrotów z tekstu, których według Ciebie warto się nauczyć. Uzasadnij, dlaczego je wybrałeś/wybrałaś i w jakich kontekstach można ich używać. Wybierz jedno z nich. Na następnych lekcjach głosujemy na „słowa tygodnia”. Musisz przekonać innych, ażeby uczestnicy kursu wybrali Twoją propozycję!

III. Wypowiedź pisemna.

1. Napisz streszczenie epizodu (maks. 100 słów).

2. Wybierz jeden z następujących cytatów z opowiadania. Napisz tekst w oparciu o wybrany cytat (min. 300 słów):

a) A my, dzieci, chłoniemy (...) wszystko. Nasiąkamy ta atmosfera. Jesteśmy dzieci gąbki. Nie wystarczy nas wyżymać, trzeba uważać, w co się nas zanurza. Nawet wymyci, wyptukani, wysuszeni wielokrotnie zachowujemy w sobie ślady. (s. 19)

b) Komunizm u nas nie zostat obalony w brutalny sposób. Zmiana ustroju nie skrzywdzita nikogo, nawet tych „złych”, co zabolało niektórych ,,dobrych”. (...) // U nas byto inaczej niż z murem w Berlinie. Buch! Bam! Grum! // Liść umiera powoli na drzewie, w końcu się od niego odrywa i zwyczajnie spada. Oto nasz koniec komunizmu. Kto pamięta o suchym liściu, który spadt? (s. 23)

Jak widać, możliwości skorzystania z komiksu w celu nauczania wiedzy o kraju (i nie tylko) na zajęciach z języka polskiego jako obcego są niemal nieograniczone, można korzystać ze wszystkich form pracy (praca indywidualna, praca w grupie, praca nad projektem itp.), przez co możliwe jest uwzględnienie wewnętrznego zróżnicowania grupy podczas lekcji. Przy okazji można pracować nad wszystkimi sprawnościami: czytanie, pisanie, mówienie i słuchanie. Lekcje można urozmaicać dzięki mediom (film, nagrania $\mathrm{z}$ radia, Internet itp.) i przede wszystkim można zachęcać uczniów do aktywnej pracy, która gwarantuje przyrost wiedzy i daje największy sukces w nauce, bo namacalnie utrwala wiedzę. Z odrobiną fantazji i kreatywności można się naukowo rozprawiać z kulturą docelową, traktując komiks jako punkt wyjściowy, który nie tylko rozwija, ale i utwierdza zdobyte znajomości (i wiadomości) z języka polskiego jako obcego. 


\section{Analizowane Komiksy}

Sowa M. / Savoia S., 2007, Marzi 1: Dzieci i ryby glosu nie maja, Warszawa.

—, 2007, Marzi 2: Hałasy duzych miast, Warszawa.

—, 2011, Marzi 3: Nie ma wolności bez solidarności, Warszawa.

\section{Bibliografia}

DitTmar J. F., 2008, Comic-Analyse, Konstanz.

Eisner W., 2008, Comics \& Sequential Art: Principles and Practices from the Legendary Cartoonist, New York.

-, 2008, Graphic Storytelling and Visual Narrative: Principles and Practices from the Legendary Cartoonist, New York.

McCloud S., 1994, Understanding Comics: The Invisible Art, New York.

Grünewald D., 1991, Vom Umgang mit Comics, Berlin.

—, 2000, Comics, Tübingen.

Sackmann E., 2008, Comic. Kommentierte Definition, [online] [dostęp 01.01.2013], http://www.comicforschung.de/pdf/dc10_6-9.pdf. 